\title{
The Black Suits of Mayday: The Turkish Cypriot Opposition in a Period of Siege
}

\author{
Nikos Moudouros \\ University of Cyprus, Nicosia, Cyprus
}

\begin{abstract}
The present article analyzes the emergence of the Turkish Cypriot state of exception in the period of intercommunal riots in Cyprus on two main levels. The first level identifies its structures and ideological aspects. The enclaves of the 1964-1974 period in Cyprus are treated as areas of exclusion and siege of the Turkish Cypriots. Therefore, they are studied as spaces that produce certain political activity against the "other" community, the Greek Cypriot community. The creation of the enclaves resulted from the armed violence of this decade; it was a direct response to an emergency situation which contributed, to a certain degree, and to the territorial and political partition of the two communities. Therefore, this article aims to describe the aspects of the nationalist hegemony and the efforts to reproduce its power through the activation of the threat. On a second level, the article studies the dynamics that led to the emergence of opposition forces and which eventually became an important aspect of the development of the Turkish Cypriot community. On this level, the paper examines the space where the Turkish Cypriots lived for a decade as areas where state power sovereignty, or the dominance of the nationalist elite, met with alternative forms of existence and with other notions of belonging that opposed the dominant ones.
\end{abstract}

Keywords: Cyprus, Turkey, Turkish Cypriots, state of exception, opposition, hegemony

\section{Introduction}

Describing how May Day was celebrated in the period the Turkish Cypriot community was secluded in enclaves, the Turkish Cypriot trade unionist, Mehmet Seyis, noted:

In those circumstances, such events were prohibited; they were presented by the dominant nationalist ideology as treason. For this reason, organized groups of people who wanted to commemorate the first of May went to taverns, initially sat in silence wearing their black suits. Others gathered in homes. (Sim, 2016)

Dressing in black was, and still is, a form of protest (Sim, 2016). The example of Seyis is particularly useful in our understanding of the evolution of the Turkish Cypriot society at a time of siege and almost complete isolation in the decade 1964-1974. It is also useful in understanding the alternative forms of resistance against the nationalism of the Turkish Cypriot elite, and in decoding a "parallel reality" that the Turkish Cypriot opposition was structuring outside the boundaries of the dominant sphere. The silent protest of trade unionists dressed in black can therefore be perceived as an example of centrifugal forces in a Cypriot state of exception, which in many aspects, falls within the theoretical analysis of Giorgio Agamben (1998; 2005).

The present article therefore seeks to analyze the emergence of the Turkish Cypriot state of exception in a

Nikos Moudouros, Dr., Post-doctoral Researcher, Turkish and Middle-Eastern Studies Department, University of Cyprus. 
period of intercommunal riots in Cyprus, to identify its structures and ideological aspects. At the same time, it examines the dynamics which led to the emergence of opposition forces and eventually became an important aspect of the development of the community both on a political level and on the level of expressing the Turkish Cypriot collective identity.

The first part of the article treats the enclaves of the period between 1964-1974 as areas of exclusion and siege of the Turkish Cypriots. They are thus, studied as spaces that produced a certain political activity against the "other" community, the Greek Cypriot community. The creation of the enclaves resulted from the armed violence of this decade; it was a direct response to an emergency situation which contributed, to a certain degree, and to the territorial and political partition of the two communities. This section of the article analyzes the double siege of the community and how nationalism operated as a reproduction of the state of exception.

The article aims, at the same time, to approach the space where the Turkish Cypriots lived as an area where state power, or the dominance of the nationalist elite, met with alternative forms of existence and with other notions of belonging that opposed the dominant ones. The second and third section of this article focus on the effort to approach the Turkish Cypriot enclaves as "spaces of denial" (Reece, 2012), i.e., spaces where the hegemonic perception and politics are confronted with the emergence and gradual strengthening of an alternative concept of space, perceived as a whole beyond the partition, and of identity as a unified concept through diversity. Specifically, the second section presents the social changes that brought about ruptures in the state of exception. The third section puts emphasis on the action of the opposition forces that emerge from the enclaves, analyzing the particular case of Kokkina (Erenköy).

\section{The Foundations of the Double Siege and the Ideology of the State of Exception}

Agamben proposed to address the state of exception as an example of governing, as well as a strategy of domination. Following this line of thought, the dominant power in such places, suspends or abolishes the law. The dominant can then, reproduce its power not only because it creates and applies the laws in an area, but also because it can create states of exception. States of exception emerge as results of different processes including violence. They can result from a total destruction of an area or from border enforcement. They may also be the result of a longstanding border conflict or of an armed conflict. They can occur as a new settlement, enclave, or secluded city (Ram, 2015). What characterizes the exception is that it is excluded from any relation with the rule. To the contrary, the rule continues its relation with the exception in the form of suspension. Therefore, as Agamben (1998) argued, the state of exception is not chaos preceding order, but a condition resulting from the suspension of the order.

The enclaves of the 1964-1974 period in Cyprus, as a state of exception, emerged as a result of violence between the two communities and the collapse of the bi-communal nature of the Cyprus Republic. According to Richard Patrick's data, the period between December 1963 and the summer of 1964 was the most violent period of inter-communal conflict during which 350 Turkish Cypriots and 200 Greek Cypriots and Greeks were killed (Patrick, 1976). Immediately, after the outbreak of the riots, the mass displacement of the Turkish Cypriots and their movement in enclaves was completed very soon. The main reason was that the Turkish Cypriots were numerically a minority compared to the Greek Cypriot population. The violence of this period more easily forced the smallest community to be displaced in areas where they could continue their life with members of the same community (Attalides, 1977). A supportive factor was naturally the immediate diffusion of fear among the Turkish Cypriots; a fear which originated mainly from the possibility of more intensified 
attacks by the armed Greek Cypriot groups. Describing the feeling of the time, the veteran trade unionist Kamil Tüncel said: "People started running scared ... for some people, this was the moment that the Greek Cypriots would attack us and slaughter us all” (Tüncel, 2011, p. 268).

Up until late December 1963, a total of 22 Turkish Cypriot villages were evacuated, while in January 1964, the residents of 55 Turkish Cypriot villages were added to the long list of refugees (Gibbons, 1969). According to data cited by Oberling, from December 1963 when the conflicts began to August 1964, a total of 103 villages were evacuated (Oberling, 1982). The mass displacement of Turkish Cypriots was accompanied by properties looting by Greek Cypriots of neighboring villages. Packard (2008) cited an excerpt in his research from the UN Secretary General report on September 10th, 1964, which highlights that up to that moment 977 Turkish Cypriot homes were completely destroyed while 2,000 more were partially looted. Occasional looting incidents also occurred in the next period. In September 1965, the Turkish Cypriot leadership published information which recorded looting incidents and damages in Turkish Cypriot properties in 102 different villages. ${ }^{1}$ As a result of the conflicts, approximately 25,000 Turkish Cypriots became refugees, a number corresponding to one quarter of the community (Bryant \& Hatay, 2009). The proportion of displacement for such a small, numerically speaking, community immediately set the base for a deep restructuring of its social and economic tissue.

The appearance of the enclaves then, was a form of response to a difficult violent situation (Simon, 2015). The enclaves were surrounded by sandbags that formed walls and trenches. For many years, these bags would become a "permanent companion" for the Turkish Cypriots and a reminder, as Zehra Elicin (2013) noted in her autobiographical text, that their life was constantly under threat. It was a state of affairs that resulted from the suspension of order. These spaces however, formed areas where the "exception" gradually became the "rule", while the population of the Turkish Cypriots acquired a dimension of a double bare life. ${ }^{2}$ On the one hand, the government of Cyprus Republic, because of the armed action of TMT (Turkish Resistance Organization [Türk Mukavemet Teşkilatı]), considered the community as "insurgents" and "rebels" against the state order. On the other hand, the Turkish Cypriot enclaves were not only the fields of "exile" and "exclusion". They were also places of complete militarization and authoritarianism, where the inhabitants were transformed into a kind of "bare life" by the Turkish Cypriot nationalist leadership. Kizllyürek describes the double "bare life" of the Turkish Cypriots as follows:

\footnotetext{
Suddenly Cyprus, as country, did not exist. There was basically one prison, from which you could not escape. The outside was the Greek, the enemy who threatened you and inside was the Turkish military figure [paşa] who ruled you. And you feared them both. (Chistodoulou, 2016)
}

At first, the Government of the Cyprus Republic took measures, such as setting up barricades, stopping telephone communications, surrounding Turkish Cypriot villages and areas, and creating obstacles to the normalization of the life of a very important part of the Turkish Cypriot community (Patrick, 1976). It was a time when the state did not set clearly the boundaries between the paramilitary activities of TMT and those of the Turkish Cypriots in general. The enclaves gradually transformed into spaces where the government would try "to reshape the insurgents" (Scheipers, 2015, pp. 678-698). The concentration of the vast majority of the

\footnotetext{
1 “Türk Sözcüsü, Makarios’un göçmenlerle ilgili son demecini cevaplandırdı”, Halkın Sesi, 25 September 1965.

2 "Bare life" (homo sacer) in Agamben's work is the life that may be killed and go unpunished, but without being a worthy sacrificial offering. Agamben Giorgio, Homo Sacer.
} 
community in enclaves and the perception that the community's existence legitimized, in a sense, Turkey's possible military intervention, were facts that enforced security measures which affected adversely the entire Turkish Cypriot population.

After the armed conflicts in Erenköy in the summer of 1964, the government realized that it could not confront, in military terms, the Turkish Cypriot community. It thus proceeded to activating economic restrictions against the enclaves (Patrick, 1976). In mid-September 1964, the government issued a list of "strategic materials" which were forbidden to enter the enclaves, such as spare parts of machines and cars, electrical equipment, batteries, fuel, building materials, and timber (Strong, 1999). The list was intended to prevent the Turkish Cypriots to access materials that could enhance their military equipment. But the fact is that the prohibition of certain materials decisively harmed both the potential for housing the refugees, as well as the productive means within the community (Patrick, 1976). The economic isolation was such that forced the UN to react to the Makarios government. According to the report of the UN Secretary General, "in some cases, isolation was so strict that it comprised a real siege, it was a sign that the government was seeking to impose a solution through economic pressure as replacement of military action". ${ }^{3}$ Until mid 1964, the economic restrictions closed completely all roads providing food to the Turkish Cypriot enclaves, and in many cases, basic goods, such as flour, rice, and sugar were not allowed (Plümer, 2008). In late 1964, and after several pressures by the UN, the government of Makarios began to relax the measures and to restore movement in some areas.

On a second level, the Turkish Cypriot nationalist leadership exploited the prevailing atmosphere deepening the gap between the two communities with additional obstacles to their contact. From early 1964, the aim of the Turkish Cypriot leadership was clear. In the given circumstances, it sought to intensify the concentration of the Turkish Cypriot population in a separate geography. Indeed, this process was not smooth. Various accounts of The United Nations Peacekeeping Force in Cyprus (UNFICYP) officers indicate that the organized armed groups exercised force and applied punitive measures to coerce the displacement of Turkish Cypriots (Strong, 1999). It was in these circumstances that the paramilitary activity of TMT surfaced. From an underground organization, it almost immediately becomes a kind of regular army (Bryant \& Hatay, 2011), whose leadership assumes the decisive part of the process of an early separate state structure. The first expression of a separate administrative structure was the General Committee (Bozkurt, 2015). This form of restructuring of the TMT was expressed through the creation of a "system of militants" (mücahit). The lower-ranked officers of the body of mücahit were leaders of TMT nuclei, former police officers of the Republic or former officers of the Cypriot army. The upper ranks with staff duties and responsibilities were occupied by officers of the Turkish army (Patrick, 1976).

This military hierarchy was accompanied by remarkable political power. The head of TMT (Bayraktar), senior officer of the Turkish army, was not under the control of any political authority. Following the findings of Achille Mbembe on the role of armed bodies in situations of siege (Mbembe, 2003), it becomes evident that in the case of the Turkish Cypriot enclaves, the only substantial freedom was given to senior commanders, whose influence "crushed" politics and its institutions. Their activity was not limited to military matters, but rather, within the context of the military mentality, they could impose political decisions and define orientations. The persecution, marginalization, and silencing of any opposing voice within the Turkish Cypriot community,

\footnotetext{
${ }^{3}$ United Nations Security Council, Report by the Secretary General on the United Nations Operation in Cyprus, S/5950, 10 September 1964, Paragraph 222, p. 63.
} 
was one of the typical duties of the TMT leader (Süreç, 2014).

This policy of military interventionism was of course one aspect of the new social reality of the enclaves. The other aspect was the depth of the militarization of the social reality. Through the mücahit system, the enclaves of the time transformed into militarized areas, in the defense of which, the entire Turkish Cypriot population was involved. According to the data of General Kemal Yamak, former commander of the Special Warfare Office (Özel Harp Dairesi) at the General Staff of Turkey, before the military intervention of 1974, the armed "militants" reached 11.174, half of whom had active responsibilities (Yamak, 2006). The complete militarization of the social life virtually meant a new division of labor, which in turn, contributed decisively to the violent exclusion of the community from the process of production (Hakan, 2014). In the example of the biggest enclave in Nicosia, more than half of the working hours of the male population were devoted to military activities, such as guarding the barricades and fortification works. The working day began at eight in the morning and by eleven o'clock men were called to their military duties. Traders and small shopkeepers were forced to close their shops and to be present in their positions (Strong, 1999). Apart from the adult male population, the mücahit system included high school students and university students whose service in military duties was naturally the main source of their livelihood (Hatay \& Bryant, 2008), as a result of the collapse of production and impoverishment of the population.

Within this environment of double siege, favorable conditions were ultimately created for the delegitimization of different demands in the community. The ideology of the state of exception was expressed through the need for national unity against the "national enemy". Within this particular ideological framework, the violence of Greek Cypriot paramilitary groups was presented as a threat to the "communal existence" of the Turkish Cypriots. Therefore, the community should be in permanent self-defense, in a struggle for survival, during which any ideological-political differentiation was deemed as treason.

This dynamic relationship reveals that a state of exception can emerge as a practical expression of a particular ideological program and be promoted by the dominant force as an ideal space, a space for realizing their visions and goals (Ram, 2015). Rauf Denktaş himself, expressing in a "disguised manner" the ideology of the state of emergency, wrote in his memoirs:

I am terrified that there are Turkish Cypriots who recognize the government of Makarios and this number increases every day.... Our slogan as community should be the denial and the questioning of the government of Makarios. We should make a wide propaganda for this purpose. The government of Makarios is not a legitimate government. The duty of every Turkish Cypriot is to not recognize it, to not pay taxes, to not cooperate with public officials.... (Denktaş, 1997, p. 29)

This agony of Denktaş for the existence of "disobedient" Turkish Cypriots operating outside the boundaries of exception, formed a reason for the reproduction of the state of emergency and for oppressive measures against the "enemy within", i.e., against different ideas that emerged within the state of exception.

In his study of the dynamics of refugee camps, Simon Turner (2015) concluded that the population within the camps is perceived as a victim of history that should rightfully have care and attention, but under no circumstances an organized political opinion. Similarly in his study, Didier Fassin (2005) clarified that in such circumstances the refugee can no longer express his political rights, he can only appear and sensitize the public opinion with his wounds. Transposing this model in the case of Cyprus, it seems that life in the besieged enclaves was, for the nationalist leadership of the community, the confirmation of how the community was victimized by the "national enemy", as well as a confirmation of the need to reproduce the state of exception. 
This meant the reproduction of a framework where any different view was politically criminalized in the name of the state of emergency. Denktaş' reactions on this are enlightening. When a group of Turkish Cypriot trade unionists visited him in 1973 to submit their claims in view of the upcoming general strike, Denktaş accused them of serving foreign political interests. The trade unionists responded that the strike is a democratic right applied in every country, and then the Turkish Cypriot leader said: "This is not 'every country"' (Süreç, 2014, p. 26).

\section{Ruptures in the Normalization of the Exception}

A very large part of the literature on the state of exception highlights the minimal margins of the "secluded" society to resist (Minca, 2007). Based on this reasoning, if the dominant force is the one imposing the state of exception (Schmitt, 1994), then it is this force that can prevent the emergence of any kind of resistance, even by applying extended violence (Edkins, 2004). The population within the state of exception has turned into a "bare life" through biopolitics, which renders any political action meaningless. However, as Nikos Trimikliniotis (2010) noted the emergency situation is intertwined with the threat against sovereignty. The state of exception itself evidences the existence of opposing forces being reproduced as threats (p. 161). Dominance over the state of exception is exercised with contradictions; it is not homogeneous and leaves room for alternative actions (Jones, 2009).

These gaps in the exercise of sovereignty and the alternatives that these create, is another object of research on states of exception. Within the state of exception, "gaps" may arise and take the form of opposition to the dominant order and restrict its influence under certain conditions. For example, a refugee camp which is, at the same time, a kind of "margin", a place of exile, is able, precisely because of these qualities, to strengthen the dimension of the subject, to strengthen the identity of the refugee (Hyndman, 2000). In this context, the "enclaved" and "exiled" life reshapes the identity of the community. Writing about his personal experience in the Kovno ghetto in Poland, Gringauz (1949) realized that this space was a moment that reinforced the Jewish "national centralization". In his study of the Palestinian refugee camp Rashidieh in Lebanon, Ramadan (2009) recorded a process that reinforced national memory, as well as a process of emerging internal competing ideological visions. Extending the analysis to other types of "irregular spaces", such as Tahrir Square in Cairo during the period of massive protests against Mubarak, he concludes that a protest camp can become a field of total resistance to the hegemonic power (Ramadan, 2012). Therefore, collective memories may appear in such closed areas, they can reshape collective identities, and create autonomous powers.

The focus on the state of exception of the Turkish Cypriot case should lead to deeper analyses that transcend its boundaries as a form of governance and domination strategy. The impact of the domestic political and economic structure, as well as the dynamics released in the above context, are crucial aspects in the effort to have a comprehensive understanding of the development of the Turkish Cypriot community. The "bare life" of the Turkish Cypriots in the enclaves was a moment of restructuring their identity; it was a process of searching for new forms of living, of survival in a chaotic situation. As mentioned above, the creation of enclaves, as a state of exception, was the response to a situation of violence. But, at the same time, it was a relatively new beginning. The old structures and hierarchies in this new beginning may lose their meaning, while new identities, political positions, and demands emerge (Simon, 2015). The enclaves of the Turkish Cypriots were the product of territorial restructuring, of a specific material reality. The new life of the Turkish Cypriots was thus characterized by a very specific and clearly delimited space, such as an enclosed area, 
neighborhood, or village. The barricades, the barbed wire and the trenches not only reminded of the emergency situation, but also delimited the Turkish Cypriot space as a separate one from the rest of society. They were the "outsiders", the "excluded" from the whole. At the same time, this territorial status of the enclaves produced a new "indigenous" identity which enhanced the local features of the Turkish Cypriot collective consciousness.

Turkish Cypriots lived together and not scattered. In some cases, they lived completely separate from the Greek Cypriots, but not in full cooperation with Turkey. Communal solidarity within the population of the enclaves, eventually turned into part of the struggle for communal existence (Bryant \& Hatay, 2011). In the course of time, the notion of communal existence, referred to the claim of acknowledging the political status of the Turkish Cypriots both by the Greek Cypriots and by Turkey. This reshaping of the Turkish Cypriot collective identity, with a reinforced expression of its local features, formed an act of distancing from the wider Turkish nation, but also a renewed dedication to the Cypriot homeland. Even as early as Özger Yaşın described the above process as follows:

We did not tarnish our Turkishness. We proved that we were worthy sons of our ancestors. All Turkish Cypriots, without exception, those from Nicosia, Larnaka, Limassol, Paphos, Famagusta, Turks from around the island, even in the most remote areas where there was a small Turkish population, bravely defended themselves against the enemy... We, Cypriots, were proud of our Turkishness in the past and said "what happiness to the person who says he is a Turk". However, now we are equally proud to be Turks, and Cypriots. From now on, we will be proud to say "what happiness to the person who says he is Turkish Cypriot". (as cited in Bryant \& Hatay, 2011, p. 641)

This "irregular" situation of Turkish Cypriots eventually created the conditions for the "gaps" to emerge in the form of political crises, of resistance, of opposition, and of a parallel reality that survived despite the authoritarianism of the hegemonic power. In January 1967 for instance, Fazıl Plümer and Niyazi Manyera resigned from the General Committee. Plümer explained the reasons for their resignation in a letter to Denktaş, vividly describing the ideological and political crisis of the time: "In this country, it is as if we experience the last days of the collapsing old Ottoman era" (Denktaş, 1977, p. 26). Apparently, the Turkish Cypriot official used the term "collapsing" to refer to a dynamic, rather than a static, process which was characterized by the problems and contradictions of the internal situation of the enclaves in the long term. Consequently, it would be important to examine, in greater detail, the economic, social, and political foundations upon which this different understanding relied and which largely comprised the ruptures of the state of exception at the time.

One of the major problems of the Turkish Cypriot community during the period of the enclaves was not only the structure of production, but also the nearly total absence of productive activities. According to the ideological program of the nationalist leadership of the Turkish Cypriots, the coexistence of the two communities, and their joint activity, formed obstacles to the implementation of a separate state building and to the policy of Partition (Taksim). The instability in the period of the intercommunal riots and the militarized form of the enclaves created the conditions for a more generalized exclusion of the Turkish Cypriot community from production and led to its complete dependence on Turkey for financing. This contradiction between the politics of Taksim and the lack of capital accumulation (Hakan, 2014), led the Turkish Cypriot leadership to more authoritarianism, and to the creation of a network of clientelist relations in order to absorb any reactions caused by the enclaved life. As it turned out, the efforts to overcome the above contradictions widened even further the vicious cycle since it could not solve the problems caused by the large-scale impoverishment of the population. This resulted in the strengthening of social criticism and of the opposing centrifugal forces. 
According to data from the Turkish Cypriot Communal Chamber, the number of Turkish Cypriots who had to receive some kind of help from the Red Cross in 1964 was 56,000, 25,000 of which were displaced, 23,500 were unemployed, and 7,500 dependents on injured or missing persons (Ertekün, 1981). The per capita income of Turkish Cypriots in 1961 was approximately 130-135 pounds, i.e., 20\% less than that of the Greek Cypriots, which reached almost 160-165 pounds. A decade later, in 1971, the per capita income of the Turkish Cypriots was 150 pounds, that is $50 \%$ less than that of Greek Cypriots which was 300 pounds (Kedourie, 2005). The situation of large population groups, such as the refugees, farmers, civil servants and young pupils, or students, in correlation with the total dependency on Turkey, eventually became a strong foundation for the emergence of "underground currents" of reaction against the state of affairs resulting from the state of exception.

The large waves of displacement proved one of the most serious problems which created social and political dissimilarities. The rapid movement of populations was one factor which created problems. Another factor was the inability to solve them, especially by providing housing to the refugees. The economic isolation imposed by the Government of the Cyprus Republic effectively prevented the building of refugee settlements and premises that could essentially shelter the refugees. The situation got worse considering that many military officials prevented the Turkish Cypriots by force from returning to their homes (Patrick, 1976). In many areas of the enclaves, the Turkish Cypriot refugees lived in abandoned premises or warehouses, often without basic infrastructure. As Tüncel (2011) remembered from his own personal experience, he managed to find shelter with his family in the area of Hamit Mandrez, a rather poor neighborhood where dozens of people resided together, staying awake for many days.

The weakness to provide homes for this population and the "unnatural" concentration of large numbers of people in temporary settlements caused, apart from misery, serious health problems. For instance, 1965 was the third consecutive winter that the Turkish Cypriot refugees remained without any housing, ${ }^{4}$ and this eventually contributed to the emergence of epidemics, such as diphtheria ${ }^{5}$ that led to the first death of a five year old girl in October $1965 .^{6}$ The description of the situation of refugees by Konur Alp, a columnist of Halkin Sesi, is very enlightening:

The view I came across was horrible. It was as if I had returned to the Middle Ages. As if that place where I had arrived took me five centuries back within five minutes. That view reminded me of the book Les Miserables by Victor Hugo; images that make any clean conscience cry. ${ }^{7}$

Thus, a great number of the refugees, who experienced impoverishment and dependency on welfare, from that point on, started to believe that the political and military leadership did not do what was necessary to solve the problem definitely and to ensure a their safe return. More importantly, a general perception that became embedded among this population was that protection of their communal existence was not guaranteed through the state of exception, as the nationalist forces insisted (Patrick, 1976).

The situation was similar for the Turkish Cypriot farmers, the vast majority of whom either became refugees, or were unable to continue their production activity because of the intercommunal riots (Hakan, 2014). At the end of 1964, approximately 100,000 hectares of Turkish Cypriot arable land all over Cyprus had been

\footnotetext{
4 “Göçmen durumunu Türk hükümetiyle görüşeceğim”, Halkın Sesi, 20 September 1965.

5 "Difteri Salgını başgösterdi”, Halkın Sesi, 8 October 1965.

6 "Rum barbarlığının sebep olduğu difterinin ilk kurbanını verdik", Halkın Sesi, 10 October 1965.

${ }^{7}$ Konur, Alp, "Göçmen durumu", Halkın Sesi, 7 October 1965.
} 
abandoned (Plümer, 2008), while up to 1965, the Turkish producers could sell products through government councils only if they had settled their debts to the Cyprus Republic (Patrick, 1976). Meanwhile, the withdrawal of Turkish Cypriot civil servants from the state structures and their employment in the new structures of the enclaves, created a huge financial burden on the budget of the Communal Chamber that could not be paid. Denktaş (1996) calculated in early January 1964 that approximately 3,000 public servants and workers could not be paid, since this cost reached 300,000 Cyprus pounds. To overcome this problem initially, they received a grant from Ankara of a monthly salary of around 30 Cypriot pounds for every public servant regardless of previous salary (Sonan, 2014). At the same time, the expanded militarization of the enclaves and the inclusion of pupils and students entailed the restructuring of the educational system for pupils on one hand and the interruption of students studies on the other. The compulsory recruitment of these young people created concerns among them and their families, as well as tensions in the structure of the mücahit system (Besim, 2011).

\section{The Parallel Space of the Opposition}

The above economic and social crisis experienced by a large part of the Turkish Cypriot community was soon expressed in multiple ways at an ideological-political level. Very soon after the collapse of the bi-communal nature of the Cyprus Republic, different approaches that questioned the orientations of the nationalist leadership of the Turkish Cypriots came to the fore. By January 1967, Aydin Sami had sent a letter to his friend and close partner Rauf Denktaş, who was in Ankara, noting that:

To expect something today from the officers of the General Committee is unrealistic. There are people there who, along with the worthy old friends who are struggling for this cause, are pioneers in the mentality of a retreating policy and who conform to the idea that in the future we will live with the Greek Cypriots. Unfortunately, they are now the majority. (Denktaş, 1997, pp. 15-16)

A few months later, in April 1967, Denktaş (1997) publicly expressed the same concern even more clearly. In an interview in the newspaper Akın he notes:

There is a group of people who see our cause as a matter to be closed soon by granting certain rights. This group says that we should supposedly define our own policy on the Cyprus issue and, if necessary, to agree with the Greek Cypriot communists.... I do not share this opinion. Even if our assumption is to give our community tranquility, this cannot be done without Turkey. (p. 117)

From the above statements, it easily becomes evident that despite the powerful separatist lines of violence, the ideological background of the state of exception had ruptures. Outside the boundaries of the dominant order, an opposing expression was emerging which, according to the concerning views of Sami and Denktaş, claimed rapprochement and agreement with the Greek Cypriots and the autonomy of politics from Turkey. Indeed, the existence of these centrifugal forces gradually strengthened to the point that it "became majority" according to the personal opinion of Sami. Attalides (1977) noted that these are expressions that confirmed the existence of a tendency for a different understanding of things "from below" (p. 84).

It thus becomes evident that a key part of the ideological-political differences that appeared in the enclaves focused on a totally different political program, outside the limits determined by the claim for Taksim. The surrounded and secluded Turkish Cypriot spaces were ultimately unable to suppress completely the appearance of demands, such as cultural pluralism that put forth the idea of co-existence and agreement with the Greek 
Cypriots, but also independence deriving from the need for autonomy from Turkey (Panayiotou, 2006). ${ }^{8}$ The most organized reflection of these alternative political visions was the political spectrum of the Left, which, despite its weaknesses, it managed to find ways to survive through the creation of a parallel socio-political reality. The expressions of the leftist opposition were certainly diverse mainly because of physical violence, because of the prohibition of organized groups and of the political-moral criminalization of those involved in such efforts.

It was no accident that the first violent reactions of the Turkish Cypriot nationalist elite against the strengthening of all these elements described in the writings of Sami and Denktaş, included the murder of the Turkish Cypriot Derviş Ali Kavazoğlu, member of the Central Committee of AKEL and the Greek Cypriot Costas Misiaoulis, also member of the Left, in April 1965. Kavazoğlu, immediately after the outbreak of the intercommunal riots, sought to expand his political activity in two main directions. One was the immediate termination of the policy for partition pursued by the Turkish Cypriot leadership. This was the reason why before his assassination, he was "warned" with threatening messages. On October 30th, 1964, he received an anonymous letter, saying: "You bastard.... The day that your soul will go to hell is near" (An, 2011, p. 82). The second direction of his activities, which complemented an alternative political program, was the effort to explain to the government of Makarios that his policy reproduced the foundations for the perpetuation of the Turkish Cypriot nationalist program. Based on the personal testimony of Tüncel, Kavazoğlu sought and had personal contacts with Makarios, during which he strongly raised the need to resolve the problems caused by the social and economic collapse of the Turkish Cypriots, as well as the need to review the policy of the economic isolation of the enclaves. Kavazoğlu insisted that such policies have facilitated the strengthening, rather than the weakening, of the manipulations of the Turkish Cypriot leadership (Tüncel, 2011).

The assassination of Kavazoğlu in 1965, on one hand tragically reminded of the consequences against a Left opposition as these were recorded in the assassinations of 1958, but on the other, it was unable to stop the objective factors that reproduced social and political criticism against the state of exception. The murder of Kavazoğlu may theoretically have operated as an action of definite distancing of the Turkish Cypriot community from AKEL and the wider left political program. However, in practice, the "seal" of the enclaves and the seclusion of the Turkish Cypriots could not stop the reemergence of new opposing processes against the nationalist program. This conclusion is reached mainly through the experiences of the Turkish Cypriots in the "cruelest" enclave of the time, that of Kokkina (Erenköy).

Kokkina was a territory of strategic importance that facilitated the transfer of artillery from Turkey to the Turkish Cypriot mücahit groups, because of its adjacency to the sea. This geographic importance of Kokkina was the main reason why in spring of 1964 armed forces began to move in the region. The aim of the state was to completely control the wider territory in a way to prevent the import of weapons from Turkey. At the same time, the Turkish Cypriot leadership, in cooperation with Ankara, mobilized Turkish Cypriot students studying in Turkey with the aim of creating an armed nucleus that could maintain control of Kokkina and continue to provide artillery. In the outbreak of the intercommunal riots, small groups of Turkish Cypriot students enrolled in military training areas in Istanbul and Ankara (Korun, 2015). From late March until late June 1964, these student groups began to arrive secretly in Kokkina and formed an armed group of about 500 people (Bryant, 2012). The first conflicts began on August 6th, 1964 and on the 8th of the same month, the Greek Cypriots

\footnotetext{
${ }^{8}$ For a comprehensive analysis on the structural features of Cyprus as a basis for the development of the political position about independence, as well as about cultural pluralism, especially in the frame of the Left,
} 
counterattacked forcing a very large part of the Turkish Cypriot population of the villages of the wider region of Tylliria to move to the enclave of Kokkina (Korun, 2015). By the end of the conflicts in September 1964, a reverse course began for the Turkish Cypriots in the enclave. The students and few residents of the region were now surrounded from everywhere, abandoned in the surrounded enclave and cut off from all assistance, information, and resources (Bryant, 2012). Any economic activity had been completely terminated while hunger and poverty (Plümer, 2008) gradually began to stigmatize the "bare life" of the people within the enclave. As Turhan Korun, one of the students in the enclaves, recalls "those days 25 people shared one bread, trying to hold on to life with some porridge" (Korun, 2015).

The deterioration of the social conditions and the deadlocks that appeared in the course of time caused even more reaction from students. Ankara did not show any real interest and no military actions were taken to help the enclaved. Life within the enclave began to initiate a kind of introspection of students, concerning the situation they experienced and the objectives of the policy implemented which resulted in cases like the enclave of Kokkina. Alpay Durduran, who later became a leading figure of the Turkish Cypriot Left, participated in Kokkina and described the situation as follows:

We felt a lot of frustration. We lived in a feeling of abandonment. As we perceived it at the time, Turkey has not doing its duty.... We lived with frustration because we knew that the loss of our friends' lives was the result of lack of care and education. (Mengüç, 2005, p. 598)

The awareness that the enclaved students "were wasted" served as a catalyst for the revision of their views in relation to the local military regime, but also against broader political orientations. This development, in turn, resulted in the emergence of an unusual organization of students within the enclave which extended to the expression of collective demands, such as the return to their studies. In this direction, the organized besieged students took dynamic measures, such as boycotting their watch-guard duties and abandoning their military duties (Korun, 2015). The "rebellious" situation and the questioning of the discipline that the military leadership of the enclave tried to impose reached to such extent as Ahmet Tolgay notes that the, "Turkish Cypriots consciously stopped to salute even their commander". ${ }^{9}$ Organized protests were often accompanied by setting fires at night (Bryant, 2012).

Therefore, by the summer of 1965, the enclave of Kokkina turned into a small political center of the opposition against the policies of Ankara and the Turkish Cypriot leadership, and questioned and challenged the dominant national program. It was within this framework that the combination of perceptions of the Turkish Cypriot enclaved students with the Left expressed the dynamic of causing ruptures to the "irreversible" nature of the state of emergency. The Turkish Cypriots in the enclave of Kokkina for instance, got the messages of the speeches of MPs of the Labor Party of Turkey. The only radio station they heard was that of Anamur in Turkey - a region almost opposite Kokkina-that was broadcasting the sessions of the National Assembly. They could thus listen to the political speeches of Mehmet Ali Aybar, leader of the Labor Party and of Çetin Altan, MP of the party at the time, whose words affected the worldview of the enclaved since "a left wind started blowing from the north toward Erenköy" (Korun, 2015, p. 101). The secret entrance to the poetry of Nazim Hikmet and to literary works, such as "All quiet from the Western Front", in conjunction with the actual experiences of the students in Kokkina, gradually radicalized their reactions against the idea of war (Korun, 2015). One of the direct results of the above process, that combined internal criticism in addressing the

9 Tolgay, Ahmet, “Destanın arka yüzü”, Kıbrıs, 6 May 2008. 
situation of community and the leadership ideology, was the creation of the foundations for anti-nationalism as well as an alternative course for the Turkish Left. From the enclave of Kokkina emerged politicians of the Left like Özger Özgür, Nacı Talat, Alpay Durduran, Hüseyin Angolemli (Bryant, 2012).

It is no coincidence that the core of the Turkish Cypriot students found in the enclave of Kokkina, upon their return to Turkey, immediately joined the powerful at the time, left movement in the country. In this way, the Turkish Cypriot youth found more fertile ground to expand to various political concepts such as imperialism and independence, but also to quests that could be adapted to the Cyprus context (Kizılyürek, 2012). Denktaş himself wrote about his personal experience with leftist Turkish Cypriot students in Ankara after a particularly intense gathering where he was a speaker:

I struggled to understand some of the young people's questions. They use so many new terms and concepts from the left vocabulary that I got the impression I was listening to a foreign language. I answered trying to guess what they were actually asking ... The discovery of a new language. A new language for a new culture. And such a culture is contrary to everything that we believe. Will the world follow the path that they show? And if so, where will this end? (Denktaş, 1997, p. 147)

This "incomprehensible" as Denktaş puts it, Left language, expressing a new culture, translated into political confrontation between the Turkish Cypriot community of the time, entailed the overcoming of the ideological limits of the state of exception. It was the proof of the survival of a different political program which emphasized the need for democratization, for cultural pluralism, for autonomy from Turkey, and a new interpretation of community identity.

The National Federation of Turkish Cypriot Students (Kıbrıs Türk Ulusal Öğrenci Federasyonu) already in 1968 focused on demands such as the creation of a "democratic order, safeguarding freedom of expression, equality, protection of the community and not the individual interests". The positions of the Federation on the Cyprus problem were even clearer when it came to the rupture with the nationalist leadership, since the program referred to "an independent and strong Turkish Cypriot community, a Cyprus without imperialist bases, independent, democratic and federal” (Öncül \& Düzgün, 1999, p. 22). The political activities of leftist students, either in Turkey or in Cyprus, gradually expanded or matured. The claims derived from issues, such as the abolition of military service and solving the problem of unemployment and even the call for a joint revolutionary action of Greek and Turkish Cypriots because they believed that the existing partitionist political and economic structures of the island constrained the true independence of Cyprus (Patrick, 1976).

Even though the real impact of the claims of the Turkish Cypriot youth may not be accurately recorded due to the structure of the community (large number of refugees, civil servants, and farmers fully dependent on financial assistance from Turkey), it seems that their presence opened a parallel and largely "threatening" space against the nationalist elite. This period recorded intense and mass protests against the new military leadership of the community that even reached the limits of a "revolt" as confessed by TMT informan. ${ }^{10}$ In his memoirs, Denktaş' (1997) reveals a letter he sent to a person under the code name "Profesör" in Cyprus, which recommended that members of the Turkish Cypriot leadership should go to places where young students of Kokkina were frequently found because "views like the independence of Cyprus and perceptions that partition is an imperialist solution" were promoted there (p. 23).

This parallel space which included the Left could not be completely silenced through the exercise of

${ }^{10}$ Kanol, TMT'nin şifreleri, p. 147. 
physical violence that had preceded. To the contrary, its survival in the enclaves was eventually expressed in various ways in the separate institutional system created by the Turkish Cypriot leadership. This particular trend was confirmed a few years later, through the dynamic trade union and political activity of Turkish Cypriot teachers, through the emergence of organized trade unions of civil servants, as well as through the establishment of CTP (Republican Turkish Party), the first political party of the opposition against Denktaş.

\section{Conclusions}

The anthropologist Mary Douglas identifies diverse cultural groups, among which the "enclave culture" (Mary, 2017, p. 11). Groups of people or communities included in the enclave culture, usually have a strong perception of borders and of their seclusion. They are distinguished by a collective identity based on their victimization by the "outsiders". What initially appears to hold society united in the enclave is that common feeling of victimization and reproduction of a real, or fabricated, threat from the outside? ${ }^{11}$

However, as Douglas notes, as a result of a number of factors such as poverty, a new generation of people is seeking to escape. In response, the hegemonic power of the enclave seeks to take action against the internal questioning. So, the fate of societies in the enclaves "is to effectively fail" (Mary, 2017, p. 12).

This article aimed to study the dynamics of the Turkish Cypriot community at the time of isolation in the enclaves. At a time when the Turkish Cypriot society was "excluded" in enclaves as a political response to a period of intercommunal violence in Cyprus. In this sense, the paper treated the enclaves of the period between 1964 and 1974, as spaces of seclusion of the Turkish Cypriot community and as fields of hegemony of the nationalist elite. This elite, in turn, sought to maintain its hegemony through the reproduction of the threat against the existence of the Turkish Cypriot community. The community thus lived in a state of double siege for several years.

The Turkish Cypriot case seems to confirm the emphasis on the "effective failure" of the enclaved societies since centrifugal forces that politicized the notion of "escape" gradually emerged. The nationalist elite of the time ultimately had to confront alternative forms of political activity. The opposition managed, to some extent, to express its rejection of the state of exception and of the position on partition. Therefore, this parallel reality of the opposition forces operated outside the boundaries of the hegemonic rule and provided new pursuits to the collective identity of Turkish Cypriots beyond the borders of nationalism.

\section{References}

Agamben, G. (1998). Homo sacer: Sovereign power and bare life. Palo Alto, CA: Stanford University Press.

Agamben, G. (2005.). State of exception. Chicago: The University of Chicago Press.

An, A. (2011). TMT'nin kurbanları (The Victims of TMT). Lefkoşa: Birleşik Kıbrıs Partisi Yayınları.

Attalides, M. (1977). The Turkish Cypriots: Their relations to the Greek Cypriots in perspective. In A. Michael (Ed.), Cyprus reviewed (pp. 71-97). Nicosia: The Jus Cypri Association.

Besim, F. (2011). Tarihe Sözüm Var: Kıbrıslı Türklerin toplumsal ve siyasal tarihine kısa bir yolculuk (My promise to History: A Short Travel to the Social and Political History of Turkish Cypriots). İstanbul: Galata Yayınlar1.

Bozkurt, İ. ( 2015). Kıbrıs türk halkı'nın siyaset kurumu üzerine deneme (The Experience of the Turkish Cypriot people towards Political Institutions). Lefkoşa: Zeytin Yayınları.

Bryant, R. (2012). The fractures of a struggle: Remembering and forgetting Erenköy. In B. Rebecca, \& P. Yiannis (Eds.), Cyprus and the politics of memory: History, community and conflict (pp. 169-194). London-New York: I.B Tauris.

${ }^{11}$ Hatay, Mete, “Enclave Kültürü ve Kutlu Adalı'nın 'Kehaneti”, Poli Dergisi, 11 September 2016. 
Bryant, R., \& Hatay, M. (2009). Suing for sovereignty: Property, territory, and the EU's Cyprus problem: GPoT policy briefs. Istanbul: İstanbul Kültür Üniversitesi.

Bryant, R., \& Hatay, M. (2011). Guns and guitars: Stimulating sovereignty in a state of siege. American Ethnologist, 38(4), 631-649.

Chistodoulou, S. (2016). Niyazi Klzllyürek: Homeland is conscience, not roots. Retrieved February 12, 2016, from http://www.philenews.com/el-gr/politismos-anthropoi/389/297096/niazi-kizilgiourek-patrida-einai-i-syneidisi-ochi-oi-rizes

Denktaş, R. (1996). Rauf Denktaş'ın hatıraları (The Memories of Rauf Denktaş) (Cilt 1, 1964). İstanbul: Boğaziçi Yayınları.

Denktaş, R. (1997). Rauf Denktaş'ın hatıraları (The Memories of Rauf Denktaş) (Cilt 2, 1965). İstanbul: Boğaziçi Yayınları.

Denktaş, R. (1997). Rauf Denktaş'ın hatıraları (The Memories of Rauf Denktaş) (Cilt 4, 1967). İstanbul: Boğaziçi Yayınları.

Edkins, J. (2004). Introduction: Life, power, resistance. In E. Jenny, S. J. Michael, \& P. Veronique (Eds.), Sovereign lives: Power in global politics (pp. 1-21). London and New York: Routledge.

Ertekün, M. N. M. (1981). In search of a negotiated Cyprus settlement. Nicosia: Ulus Matbaacilık Ltd.

Fassin, D. (2005). Compassion and repression: The moral economy of immigration policies in France. Culture Anthropology, 20(3), 362-387.

Gibbons, H. S. (1969). Peace without honour. Ankara: Ada Publishing House.

Gringauz, S. (1949). The ghetto as an experiment of Jewish Social Organization (three years in Kovno Ghetto). Jewish Social Studies, 11(1), 3-30.

Hakan, A. (2014). The political economy of state building: The case of Turkeish Cypriots (1960-1967). İstanbul: İstanbul Bilgi Üniversitesi.

Hatay, M., \& Bryant, R. (2008). The jasmine scent of Nicosia: Of returns, revolutions and the longing for forbidden pasts. Journal of Modern Greek Studies, 26, 423-449.

Hyndman, J. (2000). Managing displacement: Refugees and the politics of humanitarianism. Minneapolis: University of Minnesota Press.

Jones, R. (2009). Agents of exception: Border security and the marginalization of Muslims in India. Environment and Planning D: Society and Space, 27, 879-897.

Kedourie, E. (2005). The Cyprus problem and its solution. Middle East Studies, 41(5), 649-660.

Kizilyürek, N. (2012). Turkish Cypriot left: A historical overview. In T. Nicos, \& B. Umut (Eds.), Beyond a divided Cyprus: A state and society in transformation (pp. 169-184). United States: Palgrave MacMillan.

Korun, T. (2015). Ben de yazdım (cehlin ilme galip geldiği yillar) (I wrote too. The Years that Ignorance won over Wisdom). Lefkoşa: Havadis Yayınları.

Mary, D. (2017). A history of grid and group culture theory. Retrieved February 24, 2017, from http://projects.chass.utoronto.ca/semiotics/cyber/douglas1.pdf

Mbembe, A. (2003). Necropolitics. (L. Meintjes, Trans.). Public Culture, 15(1), 1-40.

Mengüç, A. (2005). Anılarda erenköy (Erenköy in Memories). İstanbul: Bir-Mat Matbaacılık.

Minca, C. (2007). Agamben's geographies of modernity. Political Geography, 26(1), 78-97.

Oberling, P. (1982). The road to Bellapais: The Turkish Cypriot Exodus to Northern Cyprus. New York: Boulder.

Öncül, T., \& Düzgün, Ö. (1999). Kıbrıs Türk Yüksek Öğrenim Gençliği Hareketleri 1960-1981 (The Turkish Cypriot University Students Movement 1960-1981). Lefkoşa: Nacı Talat Vakfı Yayınları.

Packard, M. (2008). Getting it wrong: Fragments from a Cyprus Dairy 1964. London: Author House.

Panayiotou, A. (2006). Lenin in the coffee-shop: The communist alternative and forms of non-western modernity. Postcolonial Studies, 9(3), 267-280.

Patrick, R. A. (1976). Political geography and the Cyprus conflict, 1963-1971. Waterloo, Canada: Department of Geography, Faculty of Environmental Studies Publication.

Plümer, A. (2008). Kıbris Ekonomi Tarihi. Sarsintılı bir devrin anatomisi (1960-1974) (History of Cyprus Economy. The Anatomy of an uncertain Period 1960-1974). Lefkoşa: Rüstem.

Ram, M. (2015). Colonial conquest and the politics of normalization: The case of Golan Heights and Northern Cyprus. Political Geography, 47, 21-32.

Ramadan, A. (2009). A refugee landscape: Writing Palestinian nationalism in Lebanon. ACME: An International E-Journal for Critical Geographies, 8(1), 69-99.

Ramadan, A. (2012). From Tahrir to the world: The camp as a political public space. European Urban and Regional Studies, $20(1), 145-149$. 
Reece, J. (2012). Spaces of refusal: Rethinking sovereign power and resistance at the border. Annals of the Association of American Geographers, 102(3), 685-699.

Scheipers, S. (2015). The use of camps in colonial warfare. The Journal of Imperial and Commonwealth History, 43(4), 678-698.

Schmitt, C. (1994). Political theology: Four chapters on the concept of sovereignty. Athens: Levathian.

Sim, K. (2015). Mehmet Seyis 1 Mayls Belgeseli 2015 (Mehmet Seyis: 1st May Documentary 2015). Retrieved January 12, 2016, from http://www.kanalsim.com/video-izle/474/

Simon, T. (2015). What is a refugee camp? Explorations of the limits and effects of the camp. Journal of Refugee Studies, 29(2), 139-148. doi:10.1093/jrs/fev024

Sonan, S. (2014). In the grip of political clientelism: The post-1974 Turkish Cypriot politics and the politico-economic foundations of pro-Taksim consensus (Unpublished Ph.D. thesis, Faculty of Social Sciences, University of Essen).

Strong, N. P. (1999). The economic consequences of ethno-national conflict in Cyprus: The development of two siege economies after 1962 and 1974. London: University of London.

Süreç, E. (2014). Bitmeyen BEY Dönemi: KTAMS ve siyasette yaşanan süreç (The Unending BEY Period: KTAMS and the Process in Politics). Lefkoşa: Ateş Matbaacılık.

Trimikliniotis, N. (2010). The nation-state dialectic and the state of exception. Athens: Savalas.

Tüncel, K. (2011). Düşmana inat: Bir gün daha yaşamak (Obstinacy against the Enemy: To live for one more day). Lefkoşa: KTÖS Yayınları.

Yamak, K. (2006). Gölgede kala izler ve gölgeleşen bizler (Traces in Shadows and us becoming Shadows). İstanbul: Doğan Kitap.

Zehra, E. (2013). Kıbrıs'ta denizi görmeden. 60'll ylllar (Without Seeing the Sea in Cyprus. The 60's). İstanbul: Cinius Yayınları. 